\title{
Sintesis Nanopartikel Bovine Serum Albumin Kombinasi Cisplatin dan Asam Folat Sebagai Kandidat Antikanker
}

\author{
Synthesis of Bovine Serum Albumin Nanoparticle Combination of Cisplatin and Folic Acid as \\ Anticancer Candidates
}

\author{
Ersalina Nidianti ${ }^{1 *}$, Ary Andini'), Nia Kurniaty Rukman ${ }^{2)}$ \\ ${ }^{1)}$ Universitas Nahdlatul Ulama Surabaya, Analis Kesehatan, Fakultas Kesehatan, Indonesia \\ ${ }^{2}$ Universitas Muhammadiyah Kupang, Pendidikan Matematika, Fakultas Keguruan dan Ilmu \\ Pendidikan, Indonesia \\ *email: ersalinanidianti@unusa.ac.id
}

Received: 04/11/20; Revised: 14/12/20; Accepted: 14/12/20

\begin{abstract}
Abstrak
Kanker adalah penyakit tidak menular yang menyebabkan morbiditas dan mortalitas di seluruh wilayah dunia. Salah satu pengobatan kanker adalah dengan menggunakan obat kemoterapi cisplatin. Namun cisplatin memiliki efek samping yang bersifat toksik jika dikonsumsi dalam dosis dan waktu tertentu. Kombinasi nanopartikel bovine serum albumin (BSA) yang mengandung cisplatin dikembangkan dengan modifikasi ikatan menggunakan asam folat sebagai solusi alternatif meminimalisir efek toksik yang dihasilkan dan mengoptimalkan sistem pengiriman obat. Tujuan penelitian adalah sintesis kombinasi nanopartikel BSA yang mengandung cisplatin dan modifikasi ikatan menggunakan asam folat sebagai kandidat antikanker. Penelitian ini dilakukan melalui sintesis dengan metode desolvasi. Hasil penelitian menunjukkan bahwa nanopartikel BSA yang dikombinasi dengan cisplatin dan asam folat telah berhasil disintesis. Analisis FT-IR menunjukkan bahwa ada gugus fungsi $\mathrm{O}-\mathrm{H}$ alkohol, $\mathrm{C}-\mathrm{H}, \mathrm{C}-\mathrm{C}, \mathrm{NO}_{2}$ yang berperan dalam sintesis nanopartikel. Analisis XRD menunjukkan adanya pergeseran peak dari NP-BSA 31,69 menjadi As-CP-NP-BSA 34,45; ukuran nanopartikel NP-BSA 2,38 nm dan As-CP-NP-BSA 2,62 nm sedangkan analisis SEM-EDX diketahui ada unsur $\mathrm{C}, \mathrm{O}, \mathrm{Mg}, \mathrm{Cl}$ dan Pt.
\end{abstract}

Kata kunci: asam folat; BSA; cisplatin; sintesis nanopartikel; toksisitas

\begin{abstract}
Cancer is a non-communicable disease that causes morbidity and mortality in all regions of the world. One of the cancer treatments is using the chemotherapy drug cisplatin, but cisplatin has toxic side effects if consumed in certain doses and times. The combination of bovine serum albumin (BSA) nanoparticles containing cisplatin was developed with binding modification using folic acid as an alternative solution to minimize the resulting toxic effects and optimize the drug delivery system. The research objectives were the synthesis of combined nanoparticles (BSA) containing cisplatin and modification of the bonds using folic acid as an anticancer candidate. This research was conducted through synthesis with the desolvation method. The results showed that the bovine serum albumin nanoparticles combined with cisplatin and folic acid were successfully synthesized. FT-IR analysis showed that the O-H functional groups of alcohol, $\mathrm{C}-\mathrm{H}, \mathrm{C}-\mathrm{C}, \mathrm{NO}_{2}$ play a role in the synthesis of nanoparticles. XRD analysis shows that there is a peak shift from NP-BSA 31.69 and As-CP-NP-BSA 34.45. The size of NP-BSA nanoparticles was $2.38 \mathrm{~nm}$ and As-CP-NP-BSA $2.62 \mathrm{~nm}$ while SEM-EDX analysis of the elements of $\mathrm{C}, \mathrm{O}, \mathrm{Mg}, \mathrm{Cl}$ and $\mathrm{Pt}$.
\end{abstract}

Keywords: BSA; cisplatin; folic acid; nanoparticles synthesis; toxicity 


\section{PENDAHULUAN}

Kanker adalah penyakit tidak menular yang paling mengerikan di seluruh dunia dalam hal morbiditas dan mortalitas (Rahmani $d k k .$, 2014). Mortalitas penyakit kanker yang terus meningkat setiap tahunnya menjadi ancaman serius bagi kesehatan masyarakat di seluruh dunia (Kashyap dkk. (2019) \& Dong $d k k$. (2019)). Berdasarkan data Kementerian Kesehatan Republik Indonesia di tahun 2018 terdapat 18,1 juta kasus baru dengan angka kematian sebesar 9,6 juta kasus kematian karena penyakit kanker (Kementerian Kesehatan RI Badan Penelitian dan Pengembangan, 2018).

Penyebab penyakit kanker tidak sepenuhnya diketahui secara pasti. Namun, kanker terjadi karena adanya perubahan genetik/mutasi genetik dari sel normal menjadi sel kanker (Rahmani dkk., 2014). Teknologi pengobatan penyakit kanker dapat dilakukan melalui pembedahan, kemoterapi, terapi radiasi maupun terapi imun (Mutiah $d k k$., 2018). Kemoterapi efektif digunakan dalam pengobatan kanker, tetapi menimbulkan beberapa efek samping seperti selektivitas yang rendah pada sel kanker, akumulasi konsentrasi obat yang rendah di lokasi target tumor, serta multi drug resisten (MDR) di dalam tubuh pasien penderita kanker (Dong $d k k$., 2019). Salah satu jenis obat kemoterapi komersial adalah cisplatin.

Cisplatin diberikan melalui intervena sebagai infus jangka pendek dalam larutan saline untuk pengobatan kanker ganas. Pemberian cisplatin pada pengobatan kanker dapat memicu proses pembelahan sel yang tidak normal dan berpotensi menyerang sel yang berdekatan (Aldossary, 2019). Penggunaan secara klinis cisplatin dibatasi karena adanya efek samping yang bersifat toksik seperti nefrotoksisitas, ototoksisitas, neurotoksisitas, hemotologitoksisitas, kardiotoksisitas, dan hepatotoksisitas. Karena efek toksisitas yang dihasilkan tersebut, penggunaan cisplatin dapat menurunkan kualitas hidup pasien penderita kanker sehingga mengurangi efek terapeutik (Qi $d k k$., 2019).

Pada beberapa tahun terakhir para peneliti telah fokus pada kombinasi nanoteknologi. Nanoteknologi dapat diartikan sebagai formasi, pengembangan, peningkatan serta eksplorasi material berukuran nano (1-100 nm) (Garg \& Garg, 2018). Nanoteknologi berperan untuk meminimalkan efek samping dari cisplatin dan meningkatkan efisiensi antineoplastik, kemanjuran obat serta dapat mengurangi toksisitas obat (Koo dkk., 2013). Nanopartikel dalam kombinasi albumin dapat mengurangi toksisitas sel kanker tanpa mempengaruhi sel normal (Dong $d k k .$, 2019). Albumin telah dikaji secara ekstensif sebagai sistem penghantar obat untuk meningkatkan kelarutan dan efek terapi obat (Koo dkk., 2013).

Tujuan penelitian ini adalah sintesis kombinasi nanopartikel bovine serum albumin (BSA) yang mengandung cisplatin dan modifikasi ikatan menggunakan asam folat sebagai kandidat antikanker.

\section{METODE PENELITIAN}

Penelitian ini merupakan jenis penelitian eksperimental yang dilakukan di laboratorium kimia kesehatan, fakultas kesehatan-UNUSA.

\section{Alat dan Bahan}

Alat-alat yang digunakan dalam penelitian yaitu: hot plate, centrifuge, instrumentasi seperti XRD, SEM-EDX, dan FT-IR. 
Bahan-bahan yang digunakan dalam penelitian: Etanol $95 \%$, Cisplatin, larutan bovine serum albumin (BSA), $\mathrm{NaOH}$, larutan Phosphat Buffer Saline (PBS), Gluteraldehid, Asam folat, akuades, aquabidest, dan sorbitol.

\section{Sintesis Nanopartikel Bovine Serum Albumin (NP-BSA)}

Sintesis nanopartikel bovine serum albumin (BSA) dilakukan dengan menggunakan teknik desolvasi, yaitu teknik pembuatan nanopartikel berdasarkan perbedaan kelarutan antara desolvating agent dengan pelarut air yang bercampur dengan BSA (Ambarwati, 2019). Larutan BSA (4\% w/v) dibuat dengan melarutkan 4 gram BSA dalam 100 $\mathrm{mL}$ akuades dan diukur dengan $\mathrm{pH}$ meter diperoleh $\mathrm{pH} 7$ kemudian ditambahkan etanol $(0,5 \mathrm{~mL} / \mathrm{menit}$ dengan interval 2 menit) serta dilakukan pengadukan menggunakan magnetik stirrer $600 \mathrm{rpm}$. Kemudian ditambahkan $8 \%$ gluteraldehid (1,7 $\mu \mathrm{L} / \mathrm{mg}$ BSA) didiamkan selama 6 jam pada temperatur ruang dan diaduk dengan magnetik stirer (600 rpm) hingga terbentuk larutan keruh. Nanopartikel yang terbentuk dipisahkan dengan menggunakan sentrifugasi 2.000 rpm selama 5 menit. Kemudian dicuci dengan Phosphat Buffer Saline (PBS) yang steril hingga pH 6. Selanjutnya nanopartikel yang terbentuk disimpan dalam desikator (Alam $d k k$., 2015). Hasil sintesis dapat dilihat pada Gambar 1A.

\section{Sintesis NP-BSA dengan Obat Cisplatin (CP-NP-BSA)}

NP-BSA yang terbentuk ditambahkan dengan obat cisplatin injeksi $10 \mathrm{mg}$ diinkubasi selama 24 jam, suhu 37 ${ }^{\circ} \mathrm{C}$ kemudian dilakukan pengadukan stirer 600 rpm kemudian ditambahkan 5 mL
$\mathrm{NaOH} 0,1 \mathrm{~N}$ (Alam $d k k .$, 2015). Hasil sentrifugasi yang terbentuk kemudian dilakukan pengeringan dengan menggunakan hotplate dan dioven pada suhu $40{ }^{\circ} \mathrm{C}$ selama 6-8 jam hingga diperoleh bentuk serbuk.

\section{Sintesis CP-NP-BSA Kombinasi Asam Folat (As- CP-NP-BSA) \\ CP-NP-BSA dimodifikasi dengan} asam folat. Asam folat ditambahkan dengan PBS \& Sorbitol dengan perbandingan 1:2:2 kemudian distirer 15 menit pada temperatur ruang $\left(28-32{ }^{\circ} \mathrm{C}\right)$. Jumlah CP-NP-BSA yang ditambahkan masing-masing sebanyak $20 \mathrm{mg} / \mathrm{mL}$ dan distirer dengan magnetik stirer selama 4-5 jam (Alam $d k k$., 2015). Hasil sentrifugasi yang terbentuk kemudian dilakukan pengeringan dengan menggunakan hotplate dan dioven pada suhu $40{ }^{\circ} \mathrm{C}$ selama 6-8 jam hingga diperoleh bentuk serbuk. Hasil sintesis dapat dilihat pada Gambar 1B.

\section{Karakterisasi dan Instrumentasi}

Hasil sintesis selanjutnya dikarakterisasi menggunakan XRD, SEMEDX dan FT-IR.

Karakterisasi nanopartikel dengan $X$ Ray Difrection (XRD) yaitu sampel yang akan dianalisis dimasukkan kedalam plat aluminium ukuran $2 \times 2 \mathrm{~cm}$, plat aluminium yang berisi sampel di karakterisasi menggunakan XRD dengan sumber $\mathrm{Cu}$ Ka1 mengatur panjang gelombang serta sudut difraksi $2 \theta$. Untuk interpretasi grafik menggunakan bantuan software Match.

Karakterisasi dengan menggunakan Spektrofotometer FT-IR. Struktur kimia sampel dapat diketahui melalui Spektroskopi Fourier-Transform Infrared (FT-IR) dilakukan dengan mencampur 2 mg sampel dengan $200 \mathrm{mg}$ medium $\mathrm{KBr}$ 
dan diubah menjadi pelet transparan. Spektra FT-IR direkam menggunakan panjang gelombang 400-4000 $\mathrm{cm}^{-1}$ (Garg \& Garg, 2018).

Karakterisasi nanopartikel dengan menggunakan instrumen SEM-EDX yaitu menyiapkan alat dan bahan, kemudian sampel dimasukkan pada alat coating (pelapisan) dan selanjutnya dimasukkan ke dalam SEM untuk dilakukan analisis.

\section{HASIL DAN PEMBAHASAN \\ Hasil Sintesis}

Nanopartikel yang terdapat pada obat-obatan kemoterapi bertujuan untuk meningkatkan bioavailabilitas, sistem pengiriman obat (distribusi obat/drug delivery), memperbaiki target obat dan release obat ke sel kanker. Sehingga diharapkan dapat meningkatkan efikasi dan mengurangi efek samping (Artini, 2013). BSA memiliki berat molekul 69,323 Da, $\mathrm{pH}$ isoelektrik sebesar 4,7 pada suhu $25^{\circ} \mathrm{C}$. Secara luas BSA digunakan untuk pengiriman obat (drug delivery) karena status medisnya, biaya murah, mudah untuk dimurnikan dan sifat yang dimiliki dapat diterima dalam industri biomedis (Nosrati $d k k$., 2018).

$$
\text { Preparasi nanopartikel BSA }
$$
dilakukan dengan metode desolvasi. Kelarutan BSA dalam air tinggi jika ditambahkan desolvating agent/pelarut pendesolvasi seperti (etanol, aseton, dan DMSO) sehingga membentuk agregat dari BSA dan ditambahkan gluteraldehid sebagai crosslinker yang didasarkan pada karakteristik fisiko kimia. Asam folat (mengandung protein) berfungsi untuk mengoptimalkan sistem pengiriman obat (Ambarwati, 2019).

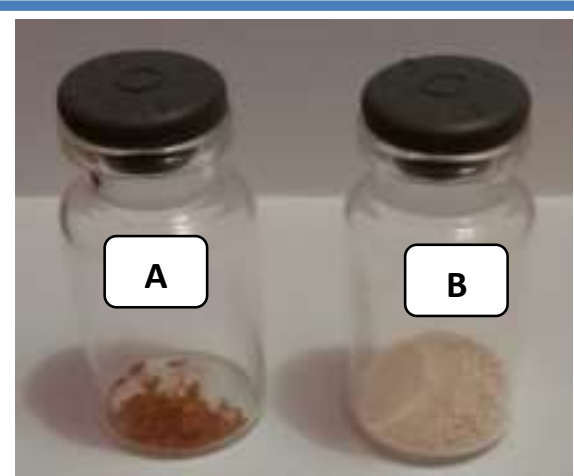

Gambar 1. A. Hasil Sintesis NP-BSA, B. Hasil Sintesis As-CP-NP-BSA

\section{Karakterisasi XRD}

Karakterisasi nanopartikel NP-BSA dengan nanopartikel As-CP-NP-BSA dilakukan dengan menggunakan instrumen XRD. Tujuan analisis XRD adalah untuk mengetahui karakteristik kristal nanopartikel yang telah disintesis dan menganalisis indeks kristalin. Pengindeks diartikan sebagai penentuan dimensi sel unit melalui posisi peak yang dihasilkan. Analisis XRD pada penelitian ini menggunakan sudut difraksi $2 \theta$ dengan sudut $10^{\circ}-90^{\circ}$ untuk semua jenis sampel (Kumaran $d k k$., 2017). Spektrum difraksi XRD untuk sampel NP-BSA dan As-CPNP-BSA dapat dilihat pada Gambar 2.

Hasil dari difraktogram puncak XRD pada NP-BSA $2 \theta$ muncul peak $31,69^{\circ}$; $45,41^{\circ} ; \quad 56,44^{\circ} ; \quad 66,28^{\circ}$ dan $75,29^{\circ}$. Sedangkan hasil difraktogram puncak XRD pada As-CP-NP-BSA yaitu $2 \theta$ muncul peak $22,51^{\circ}$ dan $34,45^{\circ}$. Hasil difraktogram terdapat pergeseran peak antara NP-BSA dan As-CP-NP-BSA dikarenakan kristal nanopartikel yang diperoleh dari sintesis belum murni (Kasim $d k k$., 2020). Perbedaan peak NP-BSA dan As-CP-NP-BSA karena komponen yang berbeda. Pada hasil sintesis As-CP-NPBSA ada penambahan asam folat, obat cisplatin dan crosslinker gluteraldehid. 
Sintesis Nanopartikel Bovine Serum Albumin Kombinasi Cisplatin dan Asam Folat Sebagai Kandidat Antikanker

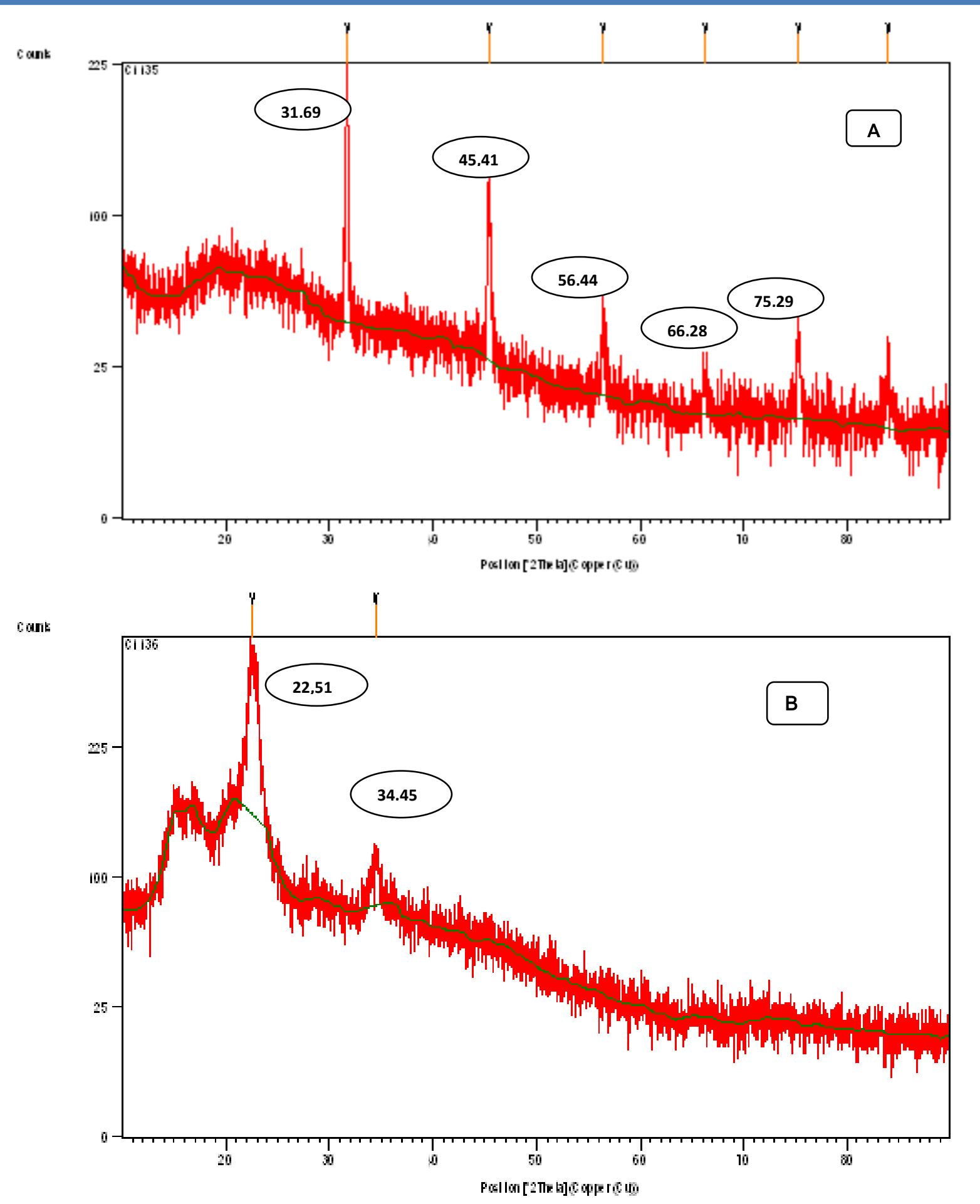

Gambar 2. Spektrum pola difraksi XRD A) NP-BSA, B) As-CP-NP-BSA

Berdasarkan analisis XRD dengan software Match menunjukkan bahwa hasil sintesis termasuk dalam nanopartikel dengan ukuran nanopartikel NP-BSA sebesar 2,38 $\mathrm{nm}$ dan As-CP-NP-BSA sebesar 2,62 nm. Untuk detailnya dapat dilihat pada Tabel 1.

\section{Karakterisasi FT-IR}

Analisis FT-IR dilakukan untuk mengetahui gugus fungsi yang terdapat dalam hasil sintesis nanopartikel As-CPNP-BSA. Profil spektrum FT-IR As-CPNP-BSA dapat dilihat pada Gambar 3 dan Tabel 2. 
Sintesis Nanopartikel Bovine Serum Albumin Kombinasi Cisplatin dan Asam Folat Sebagai Kandidat Antikanker

Tabel 1. Hasil Analisis Ukuran kristal As-CP-NP-BSA

\begin{tabular}{|c|c|c|c|c|}
\hline Sampel & $2 \theta$ & $\begin{array}{l}\text { d spacing } \\
\text { (A) }\end{array}$ & FWHM & Ukuran Kristal \\
\hline \multirow[t]{5}{*}{ NP-BSA } & 31,69 & 2,82283 & 0,2755 & $2,38 \mathrm{~nm}$ \\
\hline & 45,41 & 1,99730 & 0,3542 & $2,38 \mathrm{~nm}$ \\
\hline & 56,44 & 1,63014 & 0,3149 & $2,38 \mathrm{~nm}$ \\
\hline & 66,28 & 1,41020 & 0,4723 & $2,38 \mathrm{~nm}$ \\
\hline & 75,29 & 1,26217 & 0,3936 & $2,38 \mathrm{~nm}$ \\
\hline \multirow{2}{*}{ As-CP-NP-BSA } & 22,5169 & 3,94877 & 0,5510 & $2,62 \mathrm{~nm}$ \\
\hline & 34,4457 & 2,60300 & 0,6298 & $2,62 \mathrm{~nm}$ \\
\hline
\end{tabular}

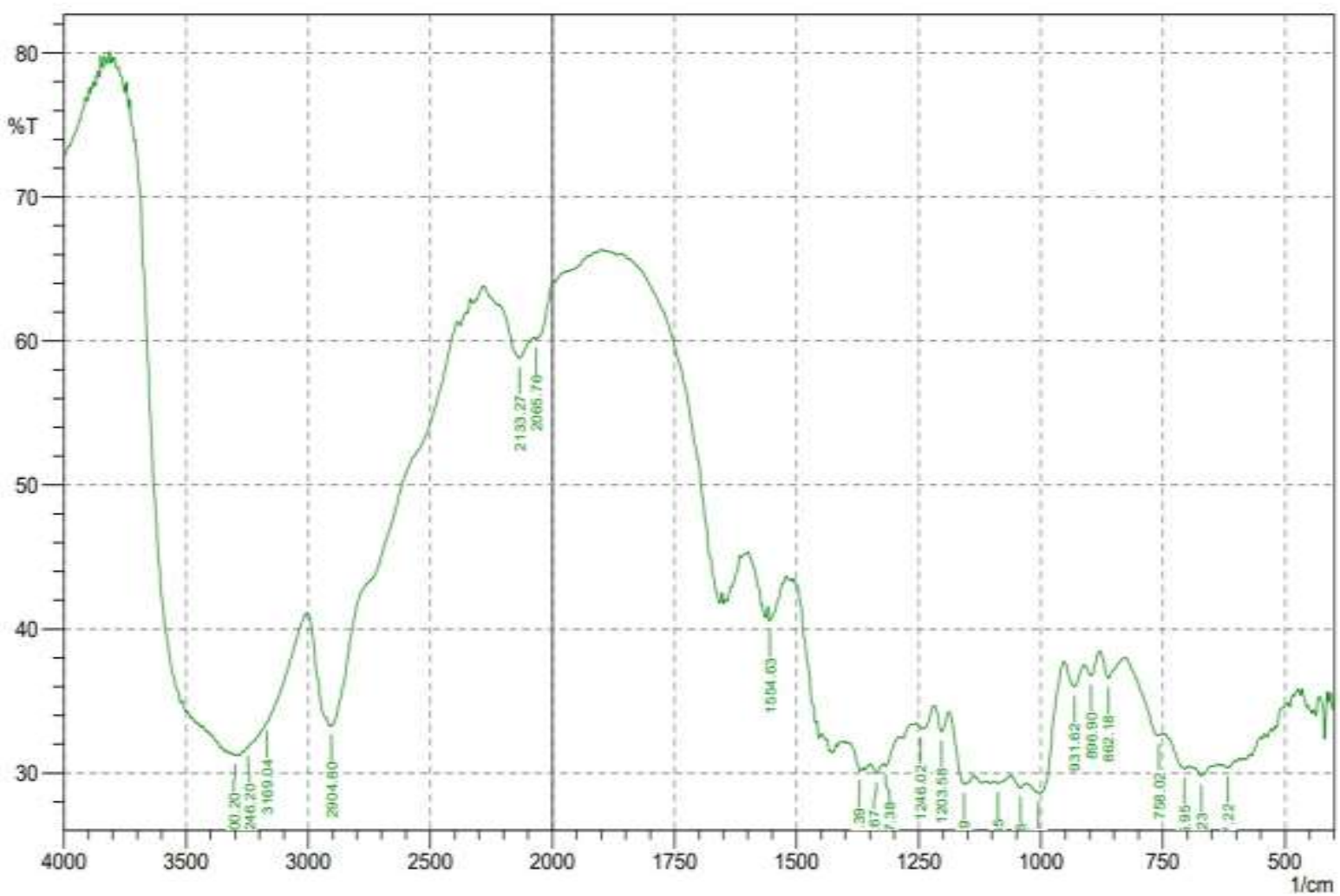

Gambar 3. Hasil FT-IR As-CP-NP-BSA

Tabel 2. Spektrum FT-IR Nanopartikel As-CP-NP-BSA

\begin{tabular}{cc}
\hline $\begin{array}{c}\text { Bilangan Gelombang } \\
\text { Nanopartikel As-CP-NP-BSA } \\
\left(\mathbf{c m}^{-1}\right)\end{array}$ & Gugus Fungsi \\
\hline 3169 & \\
$671-931$ & C-H Aromatik \\
$1041-1317$ & C-H Alkena \\
1317 dan 1554 & C-O Alkohol/Eter/Asam Karboksilat/Ester \\
1554 & NO $_{2}$ \\
2133 & C=C Cincin Aromatik \\
$1336-1371$ & C=C Alkuna \\
2065 & C-H Alkana \\
2904 & C-O \\
$3246-3300$ & C-H \\
& O-H Alkohol \\
\hline
\end{tabular}


Sintesis Nanopartikel Bovine Serum Albumin Kombinasi Cisplatin dan Asam Folat Sebagai Kandidat Antikanker

\section{Morfologi Kristal dengan SEM-EDX}

Nanopartikel memiliki bentuk dan ukuran yang beragam (Masakke $d k k$., 2015). Salah satu analisis yang digunakan untuk menunjukkan morfologi suatu kristal yaitu dengan analisis SEM. Analisis SEM menggunakan objek yang diamati secara 3D untuk mengukur ketebalan sampel. Sedangkan EDX digunakan untuk mengetahui komposisi unsur kimia dari material suatu sampel.

Hasil analisis SEM-EDX nanopartikel As-CP-NP-BSA dengan perbesaran 5000x dapat dilihat pada Gambar 4. Hasil analisis Morfologi nanopartikel dengan SEM menunjukkan bahwa nanopartikel memiliki bentuk dan ukuran yang beragam. Ukuran yang beragam diakibatkan oleh efek agregasi nanopartikel dan adanya partikel yang tidak seragam (Kasim $d k k$., 2020). Ukuran pori sebesar $20 \mu \mathrm{m}$ dapat dilihat pada Gambar 4. Sedangkan untuk unsur yang ditemukan dalam instrumen SEM-EDX yaitu unsur $\mathrm{C}, \mathrm{O}, \mathrm{Mg}, \mathrm{Pt}, \mathrm{Cl}$ dapat dilihat pada Gambar 5.

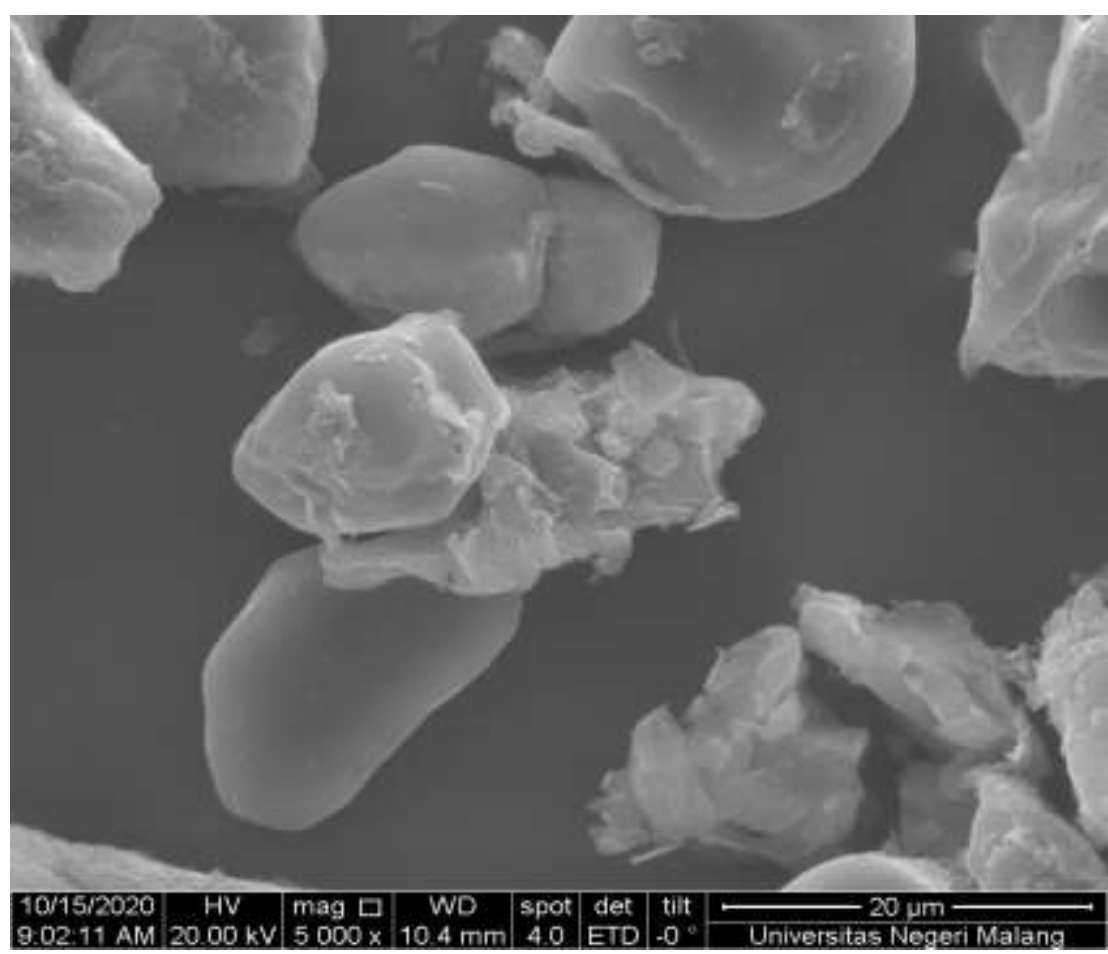

Gambar 4. Morfologi nanopartikel As-CP-NP-BSA dengan SEM-EDX

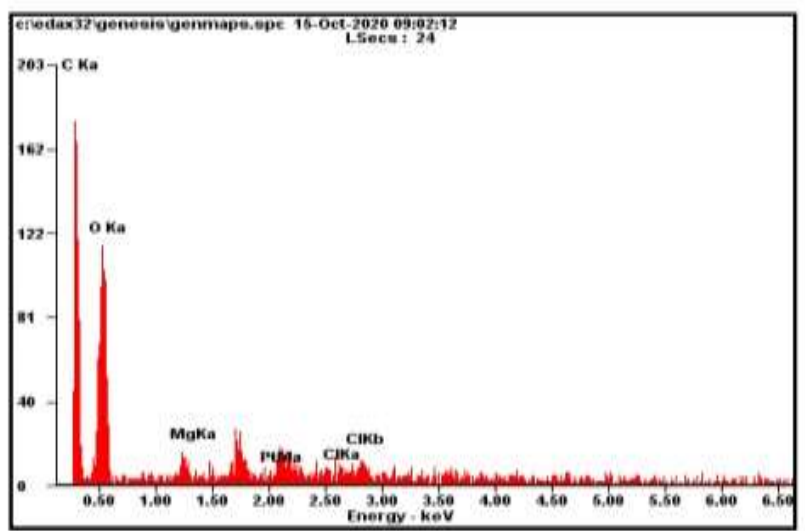

\begin{tabular}{|l|l|l|}
\hline Element & Wt\% & At\% \\
\hline $\boldsymbol{C K}$ & 52.00 & 60.41 \\
\hline $\boldsymbol{O K}$ & 44.15 & 38.50 \\
\hline $\boldsymbol{M g} \boldsymbol{K}$ & 01.30 & 00.75 \\
\hline $\boldsymbol{P t \boldsymbol { M }}$ & 02.06 & 00.15 \\
\hline $\boldsymbol{C l \boldsymbol { K }}$ & 00.49 & 00.19 \\
\hline Matrix & Correction & ZAF \\
\hline \hline
\end{tabular}

Gambar 5. Unsur dan Komposisi Unsur Hasil Analisis SEM-EDX 


\section{KESIMPULAN}

Berdasarkan hasil penelitian dapat disimpulkan bahwa nanopartikel bovine serum albumin (BSA) yang dikombinasi dengan cisplatin dan asam folat telah berhasil disintesis dengan metode desolvasi. Hasil sintesis dikarakterisasi dengan menggunakan FT-IR, XRD dan SEM - EDX. Analisis FT-IR menunjukkan bahwa adanya gugus fungsi $\mathrm{O}-\mathrm{H}$ alkohol, $\mathrm{C}-\mathrm{H}, \mathrm{C}-\mathrm{C}, \mathrm{NO}_{2}$ yang berperan dalam sintesis nanopartikel. Analisis XRD menunjukkan adanya pergeseran peak dari NP-BSA 31,69 dan As-CP-NP-BSA 34,45, ukuran nanopartikel NP-BSA 2,38 nm dan As-CP-NP-BSA 2,62 nm sedangkan analisis SEM-EDX adanya unsur $\mathrm{C}$, $\mathrm{O}$, $\mathrm{Mg}, \mathrm{Cl}$ dan Pt. Saran untuk penelitian selanjutnya perlu dilakukan pengujian antikanker secara klinis.

\section{UCAPAN TERIMAKASIH}

Penelitian ini didanai oleh hibah Penelitian Dosen Pemula (PDP), RISTEKBRIN. Perjanjian/Kontrak Nomor 083/SP2H/LT/DRM/2020; 044/SP2H/LTMONO/LL7/2020;297.25/UNUSA/AdmL PPM/IV/2020.

\section{DAFTAR RUJUKAN}

Alam, N., Dubey, R. D., Kumar, A., Koul, M., Sharma, N., Sharma, P. R., Chandan, B. K., Singh, S. K., Singh, G., \& Gupta, P. N. (2015). Reduced toxicological manifestations of cisplatin following encapsulation in folate grafted albumin nanoparticles. Life Sciences, 142, 76-85. doi: 10.1016/j.1fs.2015.10.019

Aldossary, S. A. (2019). Review on Pharmacology of Cisplatin: Clinical Use, Toxicity and Mechanism of Resistance of Cisplatin. Biomedical and Pharmacology Journal, 11(1), 07-15. doi: 10.13005/bpj/1608

Ambarwati, R. (2019). Pembuatan Nanopartikel Albumin Menggunakan Metode Desolvasi Sebagai Alternatif
Sistem Pembawa. FITOFARMAKA: Jurnal Ilmiah Farmasi, 9(1), 35-39. doi: 10.33751/jf.v9i1.1258

Artini, I. G. A. (2013). Peranan Nanopartikel Dalam Penatalaksanaan Kanker di Era Targeting Therapy. Indonesian Journal of Cancer, 7(3), 111-117.

Dong, Y., Fu, R., Yang, J., Ma, P., Liang, L., Mi, Y., \& Fan, D. (2019). Folic acid-modified ginsenoside Rg5loaded bovine serum albumin nanoparticles for targeted cancer therapy in vitro and in vivo. International Journal of Nanomedicine, 14, 6971-6988. doi: 10.2147/IJN.S210882

Garg, S., \& Garg, A. (2018). Encapsulation of Curcumin in Silver Nanoparticle for Enhancement of Anticancer Drug Delivery. International Journal of Pharmaceutical Sciences and Research, 9(3), 1160. doi: 10.13040/IJPSR.09758232.9(3).1160-66

Kashyap, D., Tuli, H. S., Yerer, M. B., Sharma, A., Sak, K., Srivastava, S., Pandey, A., Garg, V. K., Sethi, G., \& Bishayee, A. (2019). Natural product-based nanoformulations for cancer therapy: Opportunities and challenges. Seminars in Cancer Biology, June, 1-19. doi: 10.1016/j.semcancer.2019.08.014

Kasim, S., Taba, P., Ruslan, \& Anto, R. (2020). Sintesis Nanopartikel Perak Menggunakan Ekstrak Daun Eceng Gondok (Eichornia crassipes) Sebagai Bioreduktor. KOVALEN: Jurnal Riset Kimia, 6(2), 126-133. doi:

10.22487/kovalen.2020.v6.i2.15137

Kementerian Kesehatan RI Badan Penelitian dan Pengembangan. (2018). Hasil Utama Riset Kesehatan Dasar, 1-100. http://www.depkes.go.id/resources/d ownload/info-terkini/hasil-riskesdas2018.pdf 
Koo, H., Min, K. H., Lee, S. C., Park, J. H., Park, K., Jeong, S. Y., Choi, K., Kwon, I. C., \& Kim, K. (2013). Enhanced drug-loading and therapeutic efficacy of hydrotropic oligomer-conjugated glycol chitosan nanoparticles for tumor-targeted paclitaxel delivery. Journal of Controlled Release, 172(3), 823$831 . \quad$ doi: 10.1016/j.jconrel.2013.08.297

Kumaran, P., Gupta, A., \& Sharma, S. (2017). Synthesis of wound-healing keratin hydrogels using chicken feathers proteins and its properties. International Journal of Pharmacy and Pharmaceutical Sciences, 9(2), 171-178. doi: 10.22159/ijpps.2017v9i2.15620

Masakke, Y., Sulfikar, \& Rasyid, M. (2015). Biosintesis Partikel-nano Perak Menggunakan Ekstrak Metanol Daun Manggis ( Garcinia mangostana L . ) Biosynthesis of Silver Nanoparticles using Methanol Extract of Mangosteen Leaves ( Garcinia mangostana L . ). Jurnal Sainsmat, IV(1), 28-41.

Mutiah, R., Suryadinata, A., \& Nurani, P. S. (2018). Uji Sitotoksitas Kombinasi Cisplatin Dengan Ekstrak Etanol Benalu Alpukat (Dendrophthoe pentandra (L) Miq.) Pada Sel Hela. Majalah Kesehatan, 5(3), 133-143. doi:

10.21776/ub.majalahkesehatan.005.0 3.2

Nosrati, H., Abbasi, R., Charmi, J., Rakhshbahar, A., Aliakbarzadeh, F., Danafar, H., \& Davaran, S. (2018). Folic acid conjugated bovine serum albumin: An efficient smart and tumor targeted biomacromolecule for inhibition folate receptor positive cancer cells. International Journal of Biological Macromolecules, 117, 1125-1132. doi:
Qi, L., Luo, Q., Zhang, Y., Jia, F., Zhao, Y., \& Wang, F. (2019). Advances in Toxicological Research of the Anticancer Drug Cisplatin. Chemical Research in Toxicology, 32(8),14691486. doi: 10.1021/acs.chemrestox.9b00204

Rahmani, A. H., Al Zohairy, M. A., Aly, S. M., \& Khan, M. A. (2014). Curcumin: A Potential Candidate in Prevention of Cancer via Modulation of Molecular Pathways. BioMed Research International, 2014, 761608. doi: 10.1155/2014/761608

10.1016/j.ijbiomac.2018.06.026 